\title{
Sąvokų topografavimas bendradarbių laisvalaikio tyrime
}

\author{
IRMA ŠIDIŠKIENE \\ Lietuvos istorijos institutas, Kražiu g. 5, LT-01108 Vilnius \\ El. paštas: sidiskiene@istorija.lt
}

\begin{abstract}
Straipsnyje analizuojamos sąvokos, susijusios su vykdoma tema „Bendradarbių laisvalaikis. Miestiečių bendrijos kultūrinè raiška“ (1). Pagrindinès sąvokos, apimančios šią problematiką, yra laisvalaikis, darbas ir miestiečių kultūra. Remiantis antropologų, sociologų tyrimų, susijusių su šio tyrimo pagrindinėmis sąvokomis, trumpa analize, nustatytos jų tarpusavio sąsajos ir ribos, išryškintos optimaliausios tyrimo kryptys. Bendradarbių bendrijų laisvalaikio tyrimai mieste - vienas iš būdų atskleisti neformalųj mi miestiečių kultūrinị gyvenimą ir socialinius saitus.
\end{abstract}

Raktažodžiai: laisvalaikis, šventè, bendradarbiai, profesija, miestiečių kultūra

\section{IVADAS}

Apmąstydamas Europos etnologijos prasmę ir tikslą Ullrichas Kockelis pažymi, jog šio mokslo „policentrinès istorijos pasekmè buvo gyva ịvairovè ne vien pavadinimų, bet ir metodų, per kuriuos, turint omeny disciplinų visumą, atsiranda sinergijos potencialai, o jie, pranokdami paprastą pasikeitimą duomenimis bei idejomis, gali padèti kurti tarpdisciplinines inovacijas", o kad galètų disciplina „ne tik pereiti nuo vieno požiūrio prie kito, bet ir sukurti kažką visiškai nauja $<\ldots>$ etnologai turi gerai išmanyti ịvairias disciplinas, tačiau negali pasimesti paviršutiniškose metodų samplaikose, kas pernelyg dažnai neteisingai suprantama kaip tarpdiscipliniškumas" $[18,40]$. Pradedant vilniečių bendradarbių laisvalaikio tyrimus svarbu apžvelgti gretutinius tyrimus ir nusistatyti savo tyrimo prieigas. Šis žingsnis nepretenduoja ị inovacijas, tačiau privalomas, norint suvokti pasirinktos problematikos sąvokų diapazoną.

Tyrimo objektas - laisvalaikio, šventès, darbo, profesijos, bendradarbių, miestiečių kultūros sąvokos, siejamos su tema „Bendradarbių laisvalaikis. Miestiečių bendrijos kultūrinè raiška“.

Tikslas - išnagrinèti laisvalaikio, darbo ir miestiečių kultūros sąvokų ir kai kurių jų sudètinių komponentų (šventè, profesija) vartojimą sociologų, antropologų, etnologų tyrimuose, siekiant nustatyti jų tarpusavio sąsajas bei ribas ir optimizuoti tyrimo kryptis.

Keliami uždaviniai: išanalizuoti sąvokas, trumpai pristatant jų raidos tyrimuose pokyčius, ir išryškinti autorès tiriamai temai artimas prieigas. Straipsnis suskirstytas pagal vartojamų sąvokų platesnes grupes ir jų subgrupes: a) laisvalaikio, švenčių; b) darbo, profesijos,

(1) Tema vykdoma pagal Lietuvos istorijos instituto programą „Socialinė sąveika ir kultūrinė raiška mieste: laisvalaikis, šventės ir ritualai“" (2012-2016), vadovas Žilvytis Šaknys. 
bendradarbių ir c) miestiečių kultūros. Pirmiausia pateikiama sąvokų, vartojamų lietuvių ir anglų kalbose, bendroji prasmè ir pereinama prie su jomis susietų tyrimų trumpos apžvalgos.

Darbo naujumą lemia tai, kad vilniečių bendradarbių kartu praleidžiamas laisvalaikis, švenčiamos šventès ir šiose bendrijose susiformavę ar primesti ritualai Lietuvos etnologijoje iki šiol nèra tyrinėti. Miestiečių kultūros etnologiniai tyrimai apèmè šeimose vykusius procesus. Vilniaus ir Kauno miestų šeimų tyrimus 1983 m. paskelbė Antanas Daniliauskas ir Petras Kalnius: A. Daniliauskas apžvelgè darbininkų kultūrinio vartojimo (periodika, literatūra, muzika, dailè, kinas, muziejai, turizmas) problemas, o P. Kalnius - šeimos kūrimo, jos struktūros ir sudèties klausimus [11], kuriuos toliau plètojo kitose studijose [17]. Regina Merkienè taip pat apsiribojo Grigiškių darbininkų šeimų buities (gamyklos kadrų sudėtis, šeimos struktūra, maistas, gyvenamieji namai, interjeras, drabužiai) tyrimais [25]. Miesto šventès Lietuvoje atskirais laikotarpiais, nors ir negausiai, tirtos istorikų, kultūrologų, sociologų. Užsienio sociologai, antropologai nemažai dèmesio skyrẻ laisvalaikio, miesto švenčių ir organizacinès kultūros klausimams, todèl svarbu trumpai apžvelgti šiuos tyrimus.

Žmogaus gyvenime persipina darbas (užimtumas) ir poilsis. Iš pirmo žvilgsnio laisvalaikis, poilsis ir darbas - visiškai priešingos kategorijos, tačiau poilsio laikas darbe (minutès, pietų pertraukos ir pan.) taip pat būtinas. Šiais laikais laisvas laikas darbovietejje yra reglamentuojamas darbo kodekso, tačiau darbo intensyvumas ir atokvejpis koreliuoja priklausomai nuo įvairių išorinių sąlygų (darbo pobūdžio) ir vidinių, susiklosčiusių pagal dirbančiųjų bendravimo stilių (betarpiškumas / oficialumas). Laisvalaikiu darbo vietoje galima ịvardyti ir tą laiką, kai geriama kava / arbata, rūkoma ir, žinoma, kai pažymimas bendradarbio gimtadienis, kitas gyvenimo ciklo arba darbinis ịvykis, kalendorinė, valstybinè, profesinè bei kita šventè. Pastarosios šventès darbuotojų laisvalaikị susieja su formaliąja ir neformaliąja organizacine bei vietos visuomenès, kurios atstovais yra dirbantieji (šiuo atveju - miesto), kultūra.

\section{LAISVALAIKIS, ŠVENTĖS}

Lietuvių kalbos žodị „laisvalaikis“ sudaro du žodžiai - laisvas ir laikas, kuris paaiškinamas kaip „laisvas, atspejjamas nuo darbo laikas“[22]. Vadinasi, šis laikas yra suvokiamas kaip neužimtas darbine veikla. Žodis aiškiai nurodo laiko kategoriją. Anglų kalboje vartojamas leisure neturi tik vienos aiškios laiko dimensijos: apibrèžiamas kaip „laisve““ ir kaip „laisvas laikas" nuo darbo ir užimtumo reikalų. Priklausomai nuo to, kaip suvokiamas laisvalaikis, kokia jam priskiriama kategorija, tyrimas gali apimti ịvairius aspektus. Pagrindinès laisvalaikio kategorijos yra laikas, būsena ir veikla.

Laisvalaikio tyrimų problematika keičiasi kartu su besikeičiančiu žmonių laisvalaikiu, sąlygojamu skirtingų galimybių, lyčių vaidmenų, kultūrinių kontekstų [15], žmogaus gyvenimo tikslų suvokimo. Antai apšvietos filosofams (Volterui, Ruso, Kantui) laisvalaikis atrodè neutilitarus ir buvo suvokiamas kaip laiko švaistymas [33]. Toks požiūris ilgai išliko ir pirmuosiuose tyrimuose, kuriuose nagrinejjamas laisvalaikio santykis su darbu ar veikla. Čia dažniausiai laisvalaikis buvo suvoktas kaip likutinė darbo (Proper) ar patirties (Ken Roberts) kategorija. Laikytasi požiūrio, jog darbas yra viešas, socialus ir reguliuojamas, o jo priešybė laisvalaikis - individualus, laisvas, privatus $[4,6]$. Funkcionalistai manè, kad laisvalaikis priklauso nuo darbo pobūdžio $[4,8]$. Laisvalaikiui tapus komerciniu produktu, jis pradètas modeliuoti kaip vartojimo laikas. Laisvalaiko komercionalizacija ir vartojimo laisvalaikiu kilimas formavo deterministinị požiūrį, išryškejjusį Frankfurto mokykloje: suvokta, jog laisvalaikis kaip vartojimas vis labiau įtraukiamas ị kapitalistinę ekonomiką [10]. 
Lietuvoje (bei kitose sovietinėse respublikose) sovietmečiu sociologai, kaip ir minèti etnologai, tyrè darbininkų laisvalaikio kultūrą, kurią apibrèžè „kaip kasdienę kultūrinę veiklą laisvalaikiu, sąlygojančių asmenybės savikūrą, laisvalaikio bendravimą, kūrybinių poreikių tenkinimą" $[20,530]$. Kultūrinę laisvalaikio veiklą, kaip manè tyrẻjai, sudarè kvalifikacijos kèlimas ir kultūrinè veikla (kūrybinè veikla, teatrų lankymas, literatūros skaitymas, saviveikla ir visuomeninè veikla $[24,149]$, vadinasi, laisvalaikis suvoktas kaip tikslinis kultūrinis užsièmimas, kultūros vartojimas.

Vienų naujesnių tyrimų požiūriu darbas ir laisvalaikis kategoriškai nebepriešinamas ir imta manyti, kad darbas turi būti įdomus, stimuliuojantis ir darantis dirbančiuosius laimingus - darbas kaip ir laisvalaikis tapo estetiniu ženklu $[4,8]$, ịsivyravo laisvalaikio kaip pilnatvès, teigiamų santykių, socialinès harmonijos ir tvarkos terpès suvokimas.

Modernių visuomenių laisvalaikis dažnai yra emocinis centras žmonių gyvenime. Sutinkama, kad laisvalaikis - laisvė $[4,11]$. Ši kategorija susijusi ne su laiku, o su būsena. Savirealizacija pasiekiama pamiršus save laisvalaikiu ir tai žmogui suteikia gyvenimo prasmę. Laisvalaikis suvokiamas kaip vidinè žmogaus būklè, matymo būdas, žvelgimas ị pasaulį $[4,15]$.

Intensyviai nagrinètas laisvalaikis kaip veiklos kategorija, ką žmonės veikia laisvalaikiu (motyvacija, sąlygos, galimybės ir kita). Čia jis suvokiamas kaip praktika, kuri pasirenkama priklausomai nuo žmogaus kompetencijos ir žinių, kurias lemia motyvacija, vieta ir kontekstas $[32,13]$. Ši perspektyva mums yra paranki tiriant laisvalaiki darbo bendrijose, nes ìvairios veiklos atskleidžia ne tik socialines, bet ir kultūrines bendrijos sąsajas.

Viena iš sudètinių ir ryškiausių laisvalaikio formų yra šventė. Lietuvių kalboje žodis „Šventë“ vartojamas plačiai, jo prasmès susijusios dažniausiai su garbe, iškilme, džiaugsmu (rečiau su ramybe, baigtu reikalu) [22]. Šventès, apeigos (ritualas) mokslininkų tiriamos kaip kultūrinis ir socialinis fenomenas, procesas ar klasifikacija. Antai Laima Laučkaitė šventes mato kaip laiko ir socialinio sambūrio kategoriją [21]. Apibrèžiant etnologijoje vartojamo termino „šventë“ kontūrus, ̣̦ švenčių „sąrašą“ patenka ir rimtos, ir linksmos iškilmès, skirtos kažkokiai progai, dienai. Angelè Vyšniauskaitė Etninès kultūros globos tarybos pavedimu $2001 \mathrm{~m}$. pateikè šventès ir renginio atskiras apibrèžtis (2), kurias skiria šventès sakralumas, o jungia dalyvaujančiųjų pasitenkinimo jausmas [38]. Šventès terminą tyrimuose dažnai keičia ritualo (apeigų) (3) sąvoka. Ritualo apibrèžimas kito nuo siauresnès apibrèžties, apimančios religinius, sakralius veiksmus, iki „apibrěžtų formalių proginių elgsenų, perduotų ne technologijų rutinos, nurodant tikèjimus mistinèmis būtybèmis ar jègomis“ (Turner 1967 cit. pagal [16,67]). Tarp visuomenès ritualų išskiriami ir laiko perèjimo ritualai (rites), kurie atspindi laiko klasifikaciją [16, 77]. Ritualas tampa vienu iš būdų, kuriuo mes struktūruojame ir interpretuojame mūsų pasaulị $[2,267]$.

Anglų kalboje vartojami feast, feastival ir holiday žodžiai turi panašias reikšmes. Pirmasis jų, be pasikartojančios religinès šventès, iškilmių, dar reiškia puotą, o antrasis

(2) „Švente tai - visuma sakralios prasmės veiksmų, kuria nors išskirtine proga atliekamų didesnejje ar mažesnëje bendrijoje, suteikianti tos bendrijos nariams dvasinį pasitenkinimą bei fizinį atsipalaidavimą, sielos atgaivą. O šventinis renginys kažkokių visuotinai suvokiamų sakralių apeigų neturi, nors jo dalyviams taip pat gali suteikti pasitenkinimą. Šventiniai renginiai gali būti vienkartiniai ar pakartotiniai. Kasmet besikartojantys ta pačia proga jie gali tapti tradiciniais, t. y. tikra švente“ [38].

(3) „Lietuvių kalbos žodyne“ jis siejamas su religinių apeigų ceremonijomis, ceremonialu: „religinių apeigų atlikimo tvarka; religinių apeigų taisyklių rinkinys" [22], o žodžio vartojimas plito iš rašytinès kalbos. Etnologineje literatūroje lietuvių kalba terminai „ritualas“ ir „apeigos“ vartojami sinonimiškai (plačiau žr. [35, 34-35]). 
(holiday) dar žymi laisvas nuo darbo dienas. Jei žodžiu festival, kurio kilmè ir vartojimas tiesiogiai susiję su religinių švenčių eisenomis, karnavalais, puotomis [2, 120-128], šiandien dažniau įvardijami šiuolaikiniai kultūros, mokslo pasikartojantys renginiai, ypač tarptautiniai (kino, meno festivaliai - pastarasis žodis dažniausiai nebeverčiamas i lietuvių kalbą), tai holidays dažnai vartojamas kaip vacation (išeiginès dienos, atostogos) sinonimas. Kintant socialinei, kultūrinei, politinei, ekonominei aplinkai kinta ir šventès. Jos šiandien taip pat naudojamos kaip verslo produktas (atrakcija) ir nagrinejjamos (tokiuose tyrimuose vartojamas pasakymas Festivals and events - šventès (arba festivaliai) ir renginiai) ekonomikos, vadybos studijose (geografijos, turizmo, verslo) kaip būdas, pritraukiantis turistus. Kartu taip yra skatinamas įvairių švenčių ir oficialų miesto, regiono, valstybės renginių (at)kūrimas. Šiuo metu daugelis miestų igyvendina socialinès ir ekonominès pletros strategiją per festivalius, kurie organizuojami siekiant pritraukti turistus ir išplèsti kultūrinę pramoginę pasiūlą vietiniams gyventojams. Reiškinys, kai daugèja ìvairių festivalių bei didẻja jų poveikis miestams, vadinamas festivalizacija $[9,706]$.

Neoficialių ar mažesnių grupių, privačių švenčių (čia, manyčiau, labiau tinka anglų kalbos žodis holiday) tyrimų yra mažiau. Amitai Etzioni pažymėjo, kad sociologų diskurse termino holiday ìvairiose svarbiausiose sociologų enciklopedijose nèra, o Amerikos paveldo žodyne šis terminas yra apibrěžiamas kaip „ypatingo ịvykio atminimo ar šventimo dienos, kuriomis pagal papročius ar îstatymais sustabdomos bendrosios verslo veiklos" [31; 36]. Modernių Švenčių tyrimuose pabrěžiama, jog šventès šventimu, renginiu, skirtu kažkokiai progai paminèti, siekiama formuoti ir palaikyti bendrą valstybės oficialią̧ą ar organizacinę kultūrą, kuri skatintų bendruomenès sutelktumą, atsinaujinimą. A. Etzioni manymu, šventès (holiday) ir ritualai gali būti tiriami ne tik kaip visus jungiantys, bet ir skaidantys (A. Etzioni ginčija Durkheimo prielaidą apie glaudžią teigiamą koreliaciją tarp renginio bei dalyvavimo šventèse ir visuomenės integracijos). Autorius išskiria kelis tokius prieštaravimus minètai integracijos prielaidai [12] (4). Manyčiau, svarbu atkreipti dėmesị ne tik ị integracinius bei dezintegracinius švenčių aspektus, bet ir jas kaip terpę (ar būdą), kai socialiniai kultūriniai ar kiti pokyčiai, inovacijos „iteisinamos“, integruojamos ir tampa norma konkrečioje visuomenėje, grupeje.

\section{DARBAS, PROFESIJA, BENDRADARBIAI}

Jau minejjau, kad laisvalaikis glaudžiai susijęs su darbo kategorija. Darbas lietuvių kalboje apibrèžiamas kaip „tikslingas, visuomenei naudingas žmogaus veikimas, reikalaujantis protinių ar fizinių jègu ittempimo, dirbimas, veikla, triūsas" [22], o anglų k. work bendriausioji prasmè analogiška: fizinès ar protinès pastangos arba veikla, nukreipta į kažko gamybą ar pasiekimus ([36]). Darbas (kaip fenomenas, reiškinys) ir su juo susiję socialiniai, ekonominiai ar kiti santykiai yra ịvairių sričių mokslinių tyrimų centre. Socialinėje ir kultūrinèje antropologijoje su darbu susiję tyrimai plètojosi įvairiomis kryptims, ir tai rodo sąvokos ir fenomeno ịvairiabriauniškumą: JAV buvo plètojama industrinè (pramonès), darbo, organi-

(4) Pirmiausia,vienos šventės yra labiau integruotos visuomenėje, kaip ir atskirose visuomenės grupėse, nei kitos. Švenčių teorija, autoriaus manymu, padeda suvokti, jog vienos šventès, švenčiamos atskirose etninėse bendrijose, gali stiprinti tarpusavio integraciją, tačiau kartu didinti santykių fragmentaciją plačiojoje visuomenèje. Panašios problemos matyti privatizavus viešas šventes, ir tai taip pat kenkia visuomenès integracijai. Nėra aiški švenčių kaitos dinamika (pasikartojančia seka ar cikliškai konkrečioje visuomenejje). Sveikai logikai prieštarauja tai, kad religinès institucijos sąmoningai keičia šventes, kad neatitolintų daugumos sekejų, skirtingai nei pilietinès institucijos. Pastebimi nekoreliuojantys lyties vaidmenų pokyčiai visuomenejje ir švenčiant šventes. 
zacijų ir immonių, taip pat vadybos, taikomoji ir ekonominè [27, 3], dizaino antropologijos; Europos šalyse ịsitvirtinusi organizacijų antropologija (dabar orientuojasi ị kultūrų ịvairove grindžiamą požiūrị studijuoti organizacines problemas) [23, 25]. Kiekviena iš paminètų tyrimų krypčių stengiasi apibrěžti atitinkamas savo nišas: industrializacijos, organizacines, prekybos ir t. t. Šiame tyrime nebus gilinamasi ị darbo organizacines (oficialiųjų veiklų) problemas, čia aptarsime darbo bendrijos neformaliąsias veiklas, padedančias suburti bendriją, palaikyti ir plètoti kultūrinius, socialinius sąveikos saitus bendrijoje ir už jos ribų. Šiam tikslui pasiekti paranku remtis tyrimais, atliktais organizacinès ir profesijos antropologijų sferoje.

Organizacijų etnografija analizuoja visų rūšių praktikas, artefaktus, subjektus ir situacijas. Šie tyrimai orientuojasi ị kultūros ir simbolių išteklių svarbą gaminant, skirstant ir atribojant kolektyvines vertybes. Yra pripažįstama, jog organizacijos plètoja skirtingus emocinius ryšius, kolektyvo palaikomus tikejjimus, kurie skatina organizacijos narius elgtis tam tikru būdu. Šie tikejjimai yra ideologijos, paremtos abstrakčiomis idejjomis, išreikštomis konkrečiais simboliais, ritualais, mitais, pasakojimais ir pan. (užimtumo, profesinès subkultūros) [26]. Pastaruoju metu tyrèjai siekia atsiriboti nuo kolektyvinių vertybių, tolti nuo santykių tipų (pvz., solidarumas, konfliktas, bendradarbiavimas, gamyba, susvetimejjimas), kuriančių socialines situacijas, tyrimų $[8,16]$. Tačiau formalioji organizacinè teorija rutuliojasi toliau atskirai, nekreipdama dèmesio ị tokią kritiką. Tyrimai rodo, kad neformalioji organizacija bendrovès viduje labai kontrastuoja su formaliaja organizacija (korporacijos taisyklių ir politikos apibrèžtos sąveikos), kurią vadovai įdiegè, siekdami bendrovès keliamų tikslų $[1,6]$. Neformalūs darbiniai santykiai teikia pasitenkinimo darbu jausmą, palaiko sanglaudą $[28,24]$, todèl išsiplètojo taikomoji antropologija (vadybininkų). Čia taikomomis praktikomis (komandinio darbo igūdžių (team building), komandos tarpusavio supratimo (team training), domejimosi darbu (team spirit) ugdymas ir kitos veiklos) siekiama pagerinti komandos veiklą, efektyviau atlikti darbus ir pasiekti geresnių rezultatų. Siekdami sukurti gyvybiškesnę darbovietę darbdaviai įtraukia ịvairių progų šventimą, kad sukurtų džiugią nuotaiką, kad visi jaustųsi kaip namie. Švenčiamos ne tik religinès, bet ir pasaulietinès ar organizacijos įsteigimo šventès. Metinėmis šventėmis siekiama sutvirtinti bendrovès tikejjimą, kad visi darbuotojai yra didelè šeima [5]. Taip dažniausiai padedant vadybininkams kuriama organizacijos kultūra. Viena vertus, šiuo atveju oficialioji ir neformalioji kultūra neišsiskiria, kita vertus, neformuojant organizacinès kultūros, oficialioji ir neformalioji kultūros dažnai nesusisieja.

Organizacinès, verslo ir kiti antropologai bei sociologai pastebejjo naują reiškinị - socialinių tinklų darbo bendriją, kurią sudaro savos srities specialistai, besidalijantys informacija, patirtimi sprendžiant iškilusias darbo problemas. Šios bendrijos vadinamos praktikos bendrijomis ir yra intensyviai tiriamos. Jų tyrimo sfera labai artima profesijų fenomenui.

Profesija apibrèžiama kaip „darbinès veiklos rūšis, kuriai reikia spec. pasirengimo ir kuri yra pragyvenimo šaltinis“, o anglų k. profession - užimtumas, karjera, taip pat ir jos mokymasis, su ja susiję tikejimai (5). Profesijas tiria sociologai, antropologai, istorikai. Antai profesijų sociologija, savo pradžią siejanti su 1933 m. išèjusia A. M. Carr-Saunderso

(5) „Lietuvių kalbos žodyne“ aiškinama kaip nuolatinè specialybė; veiklos, užsièmimų rǔšis, kuri reikalauja tam tikro pasirengimo ir yra pragyvenimo šaltinis (http://www.lkz.lt/startas.htm); žodis profesija yra kilęs iš lot. k. professio - pasisakau; paskelbiu savo pavardę, turtą verslą [30, 603]; pagal „Collins English Dictionary“ [7] - išpažintis, deklaravimas savo tikèjimo ir pan, kilęs iš professio, reiškiančio religinių ižadų davimą. 
ir P. A. Wilsono knyga „Profesijos“, yra tiesiogiai susijusi su darbo sociologija (tyrè profesijų tipologijas, funkcijas, profesionalizacijos klausimus) [29, 16-34]. Rusų sociologų 2004 m. ivykusio seminaro pagrindu parengta publikacija ittraukia $\mathfrak{i}$ "profesijos antropologijos“ studijas, paremtas etnografiniu tyrimu [39]. Ivadiniame straipsnyje Romanovas ir Jarskaja Smirnova profesijos antropologiją apibrèžia kaip konkretų metodologini priejjimą tiriant ivvairius profesijų ir profesinių grupių plačiąja prasme kasdienius aspektus (jie profesijų antropologiją apibrèžia darbo, organizacijų antropologų tyrimų pagrindu). Esmine šių studijų samprata laikoma kultūra.

Šia kryptimi pastaruoju metu dirbanti folkloristė T. Ščepanskaja išleido monografiją, skirtą neformalios tradicijos fenomenui profesinejje sferoje. Čia tradicija suvokiama kaip ženkliškas fenomenas - simboliškai normatyvinis kompleksas, egzistuojantis vienoje ar kitoje profesineje terpeje stereotipizuotų formų elgsenoje, diskurse, simboliuose ir interpretavimo taisyklèse, kurios tiesiogiai transliuojamos kasdienejje komunikacijoje [40, 3]; šios tradicijos tiriamos tik egzistuojančios neformaliu lygmeniu. Profesija, jos manymu, negali būti apibrèžiama kaip bendrija (rus. сообщество), nes ji ne organizacija - jos ribos, narystė ir pats buvimas aiškiai neapibrèžti, skirtingai nei organizacijos, kur naryste formaliai nustatyta [40, 22]. Profesijos kaip „isivaizduojamos bendrijos“ ribos profesionalų gali būti brèžiamos plačiau nei jų darbo kolektyvas ar vietos bendruomenė. İsivaizduojama bendruomenè palaiko ryšius simboliniais vaizdais (rus. oбpazı), tapatumo simboliais [40, 25]. Apsibrèžusi profesijos ribas autore pripažino, kad profesinę neformaliąją kultūrą kuria ne tik profesionalai, tiesiogiai atstovaujantys profesijai, bet ir kartu su jais dirbantys kitu profesijų atstovai, pvz., aktorių bendrijoje kartu dirbantys grimo, kostiumo profesijų atstovai, todèl ji mano, kad ši subkultūra yra persipynusi. Remdamasi JAV antropologų tyrimais, ji profesijai priskiria tokius bendriausius ,ženklus: užsièmimo specializaciją, priskyrimą tam tikrai socialinei grupei, žinojimą kaip profesionalo statuso patvirtinimą, specialų pasiruošimą ir formalų licencijavimą, profesinę etiką, profesijos autonomiją ir profesinị tapatumą" $[40,13]$. Pastaroji tyrimų kryptis yra susijusi su profesinès grupès tapatumo ir identifikavimo problematika, kartu atskleidžianti neformaliosios profesinės kultūros apraiškas ugdant profesionalumą. Tokie tyrimai, sakyčiau, krypsta ị profesijų kultūrinių savitumų paieškas, o bendradarbių kaip miestiečių bendrijos laisvalaikio tyrimai, manyčiau, paliečia tiesioginius kolektyvo saitus (ne įsivaizduojamus, o realiai patiriamus kasdien), ir per šių bendrijų laisvalaikio veiksmus galime stebèti jų kultūrinę raišką.

Terminas bendradarbiai yra sudarytas iš dviejų žodžių - bendras ir darbas. „Lietuvių kalbos žodynas" nurodo dvi jo reikšmes: pirmoji, plačiausia, - bendro darbo žmogus ir kita, specifinè, - kas laikraščiui rašo, jo straipsnių autorius. Abu jie akcentuoja bendru darbu užimtus žmones, o terminas darbuotojas šio bendrumo neišreiškia ir pažymi tik žmogaus užimtumą - kas darbuojasi, veikejjas [22]. Anglų kalboje atitikmenys coworker (co-worker) arba fellow worker taip pat reiškia darbuotojus, kartu atliekančius darbą (jungtis - darbas): tas, kuris dirba su kitu [36]. Wisegeek internetinejje svetainėje nurodoma [37], kad žmonès mėgsta atskirti bendradarbị (coworker) ir pavaldini (subordinate) arba vadovą (supervisor), kurių pirmąji (bendradarbị) laiko to paties statuso kolega, ne kažką aukščiau ar žemiau kompanijos lygmeniu. Bendradarbiai gali turèti organizacijoje vienodas ar panašias pozicijas bei dažnai vienodus jejgos ir autoriteto lygmenis. Tai juos jungia, išskyrus vadovus, kurie duoda nurodymus. Dauguma žmonių tikisi, kad jų lygiateisis būvis su kolegomis užtikrins toki pat traktavimą (elgimąsi) ir gerus darbo santykius. Kadangi bendradarbiai dirba kartu vienoje erdveje daug valandų, jie gali susidraugauti ir palaikyti draugiškus ryšius ir už 
darbovietès. Kiti žmonès gali laikytis nuošaliai, būti diplomatiškesni, bet nebūtinai draugiški su kartu dirbančiaisiais ir aiškiai atskirti darbo ir asmenini gyvenimą. Šios uždaros erdvès gali nukreipti santykius opozicine linkme, kai kurie žmonès turi visiškai priešiškus santykius su savo kolegomis. Darbdaviai stengiasi išlaikyti profesionalius ir neutralius santykius tam, kad užkirstų kelią ịvairiems kaltinimams, įžeidinèjimams ar kitam netinkamam elgesiui [37].

Žodis bendrija greta bendradarbių dažnai reiškia papildomus, ne tik darbinius, dirbančiųjų saitus. Lietuvių kalboje žodis siejamas su susivienijimu, draugija, jungiama bendro tikslo, ir yra draugystès sinonimas [22]. Panašios prasmės yra anglų k. žodis community; jo antroji reikšmé, nurodoma žodyne, - „žmonių grupé, turinti bendrų interesų: mokslo bendruomené; tarptautinè verslo bendruomenè “ [36]. Pagal minètą temą atliekant vilniečių bendradarbių laisvalaikio tyrimus, aiškinamasi ir bendradarbių bendrijos sąvokos esmine prasmè. Paklausti, kas yra bendradarbių bendrija, neretai pateikejjai suklūsta, kiek pamąsto. Vieni sako: „niekad nepagalvojau apie tai“, kitiems nekyla jokių abejonių - atsakymas būna pakankamai aiškus: kolegos, su kuriais draugiškai, maloniai bendrauji dažnai ir ne darbo reikalais. Vadinasi, bendradarbių bendrijos sąvoka rodo glaudesnę sąjungą tarp dirbančiųjų nei profesijos, kolegų ar darbovietès narių.

\section{MIESTIEČIŲ KULTŪRA}

„Lietuvių kalbos žodyne“ kultūra pirmiausia apibūdinama kaip „visa, kas sukurta žmonių visuomenès fiziniu ir protiniu darbu“ [22]. Anglų k. culture - „paveldètų idejjų, i̇sitikinimų, vertybių ir žinių visuma, kuri sudaro bendrus socialinio veiksmo pagrindus“ [6]. Nors bendraja prasme kultūra moksliniuose tyrimuose ir apibrèžiama ịvairiai, paprastai būna pažymimi tyrimo krypties aspektai, pvz., tirdamas amerikiečių kultūrą ir charakterị C. S. Fisheris ją nagrinejja kaip rinkinị bendrai naudojamų, laisvais ryšiais paremtų, laikomų savaime suprantamų taisyklių, simbolių ir tikejjimų, kurie apibūdina žmones. Šiuo atveju kultūra suvokiama kaip pripažinta, ilgalaikè, kontroliuojama tokių institucijų kaip šeima, teisè, menas ir religija [13, 10]. Anksčiau straipsnyje minèta organizacinė kultūra suvokiama panašiai kaip ir kultūra bendrąja prasme: „ji yra dinamiška, joje atliekami strateginiai pasirinkimai, koegzistuoja skirtingi realybės konstruktai bei nustatomos skirtingos struktūros ir klasifikacijos (pvz., mes / jie skirtumas)“. Kultūra ir kultūrų vidinè dinamika yra persipynę su skirtingų grupių skirtingomis jègomis $[23,26]$. Miesto ar miestiečių kultūrą galima tyrinèti kaip oficialiąją, viešąją (miesto) ar neformaliąją (miestiečių), nors skirtis čia nedidelè. Pastaruoju metu išryškèja antropologų, etnologų atliekamų tyrimų tendencija - tirti miesto gyventojų ir svečių tapatumus per santykị su oficialiąja miesto kultūra.

Miesto kultūra, pasak Aleksandros Bitušikovos, tai - sistema materialių objektų ir nematerialių fenomenų, procesų ir prasmių praktikų, kurios formuoja specifinį miesto ịsivaizdavimą ir tapatumą $[3,282]$. Bankla Soukupová įvadiniame straipsnyje „Objectives and Program of The English Edition of the Journal of Urban People“ teigia, kad „miestas“ reiškia bendrą ir simbolinę aplinką, tam tikru mastu savarankišką ir daugialypiai bei individualiai patiriamą [34]. Anna Kuczyńska pripažista, jog nèra vieno bendro klausimo, kurị kelia ir îvardija tyrimai apie miestą, šiuo atveju - sostinę. Šiuos tyrimus ji vadina daugiabalsiškumu (santykis su oficialiąja kultūra - per tapatumus). Antropologas Varšuvoje yra savas mieste, su savo gyvenamu pasauliu jame. Tai, kas yra „vadinama „antropologine vaizduote“, lydi

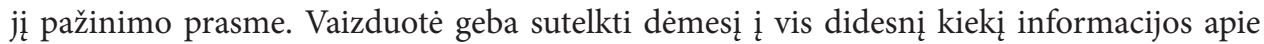
miesto gyvenimą ir iš naujo atrasti vis naujas prasmes. Tada galite kreiptis ị savo atminties 
patirtị - ilgametis gyvenimas kaimynystejje, vaikščiojimas pažistamomis gatvėmis, dalyvavimas miesto bendrijų veikloje“ [19]. Taigi dažniausiai miesto kultūra minètų žurnalų bendradarbių tiriama atskleidžiant miestiečių tapatumus. Kita plati sritis, kaip jau minejjau, kuriai daug dèmesio skiria ekonomika, verslo antropologija, turizmo antropologija ir kt., yra festivalių fenomenas miestų kultūroje. Savo tyrime išskiriu oficialiąją ir neformaliąją miesto kultūrą, jos tarpusavyje yra persipynusios ir dinamiškos. Miesto kultūra gali būti suvokiama kaip oficialioji, formuojama viešai pasitelkiant įvairius valdžios valdomus ir gyventojų palaikomus socialinius tinklus. Viena iš tokių išraiškos formų - vieši renginiai, šventès (taip pat festivaliai ir profesinès šventès). Kita miesto kultūros dalis yra neformalioji, viešai nedemonstruojama kaip miesto, t. y. nereglamentuota, savaiminé, netgi kasdiené, vietinè liaudies arba oficialiosios miesto kultūros „subkultūra“. Pastarajai priskirčiau ir neformalųji bendradarbių bendrijos laisvalaikį.

\section{IŠVADOS}

Nors, kaip teigè Mathias Frimanas, tyrimas disciplinos paribiuose iš tiesų brèžia naujas ribas, jos yra atviros ribų kirtimui ir alternatyviems rėminimams sprendžiant konkrečius klausimus $[14,15]$. Remiantis antropologų, sociologų tyrimų, susijusių su šio tyrimo pagrindinemis sąvokomis, trumpa analize, nustatytos sąvokų tarpusavio sąsajos ir ribos, išryškintos optimaliausios tyrimo kryptys. Bendradarbių bendrijos sąvoka yra greta organizacijų kultūros ir profesijų antropologijos subjektų kaip jas sujungianti, todèl leidžia išplèsti tyrimo lauką. Miestiečių laisvalaikis suvokiamas kaip praktika, kuri pasirenkama priklausomai nuo žmogaus kompetencijos ir žinių, todèl šiuo atveju laisvalaikio tyrimu galima atskleisti miesto žmogaus pasirinkimo galimybes, motyvacijas, sąlygas ir kita. Bendradarbių bendrijų laisvalaikio tyrimai - vienas iš būdų atskleisti neformalųjị miestiečių kultūrinị gyvenimą ir socialinius saitus.

Gauta 20131216

Priimta 20140909

\section{Literatūra ir šaltiniai}

[1] BABA, Marietta L. Anthropology and Business. Encyclopedia of Anthropology. Ed. H. James Birx. Thousand Oaks, CA: Sage Publications, 2006, p. 1-51.

[2] BELL, Catherine. Ritual. Perspectives and Dimensions. New York, Oxford: Oxford University Press, 1997.

[3] BITUŠÍKOVÁ, Alexandra. Trends in Urban Research and their Reflection in Slovak Ethnology / Anthropology. Urban People / Lidé města, 2010, Nr. 2(12), p. 273-290.

[4] BLACKSHAW, Tony; CRAWFORD, Garry. The Sage Dictionary of Leisure Studies. SAGE Publications Ltd, 2009.

[5] Celebrations at Workplace [žiūrèta 2013 05]. Prieiga per internetą: <http://www.naukrihub. com/hr-today/celebrations-at-workplace.html>.

[6] Collins English Dictionary - Complete and Unabridged. Harper Collins Publishers, 2003 [žiūrèta 2013 05]. Prieiga per internetą: <http://www.thefreedictionary.com/>.

[7] Collins English Dictionary - Complete \& Unabridged 10th Edition. William Collins Sons \& Co. Ltd., 2009 [žiūrèta 2013 05]. Prieiga per internetą: <http://www.thefreedictionary.com/>.

[8] CORSíN, Jiménez Alberto. Introduction: Re-Institutionalisations. Anthropology of Organisations Reader [žiūrèta 2013 05]. Prieiga per internetą: <http://digital.csic.es/bitstream/10261/17972/1/IntroductionAnthropologyOrganisationspreprint.pdf $>$. 
[9] CUDNY, Waldemar; KOREC, Pavol; ROUBA, Rafał. Resident's Perception of Festivals - a Case Study of Łódź. Sociológia, 2012, Vol. 44, No. 6, p. 704-728.

[10] Dictionary of the Social Sciences. Ed. Calhoun Craig. Oxford University Press, 2002 [žiūrèta 2013 11]. Prieiga per internetą: <http://oupacademic.tumblr.com/post/63372339537/free-accessto-oxford-content-during-the-government $>$.

[11] DANILIAUSKAS, Antanas; KALNIUS, Petras. Lietuvos TSR pramonès darbininkų kultūros ir šeimos etnografinés problemos. Vilnius: Mokslas, 1983.

[12] ETZIONI, Amitai. Toward a Theory of Public Ritual. Sociological Theory, 2000, Vol. 18, Nr. 1, p. 40-59 [žiūrèta 2013 08]. Prieiga per internetą: <http://www.gwu.edu/ ccps/etzioni/A275.html>.

[13] FISHER, Claude S. Made in America. A Social History of American Culture and Character. Chicago and London: The University of Chicago Press, 2010.

[14] FRIMAN, Mathias. Understanding Boundary Work through Discourse Theory: Interdisciplines and Interdisciplinarity. Science Studies, 2010, Vol. 23, Nr. 2, p. 5-19.

[15] HENDERSON, Karla A. Leisure. The Oxford Encyclopedia of Women in World History. Ed. G. Smith Bonnie. Oxford University Press, 2008 [žiürèta 2013 11]. Prieiga per internetą: <http://www. oxfordreference.com/view/10.1093/acref/9780195123715.001.0001/acref-9780195123715-e-645\#>.

[16] HENDRY, Joy. An Introduction to Social Anthropology. Other People's Worlds. Basingstoke and London: Macmillan Press, 1999.

[17] KALNIUS, Petras. Miesto šeimos etnodemografiniai bruožai ir vidaus organizacija XIXXX a. Ǐs: A. Vyšniauskaite, P. Kalnius, R. Paukštytè. Lietuvių šeima ir papročiai. Vilnius: Mintis, 1995, p. $168-219$.

[18] KOCKEL, Ullrich. Kam reikia Europos etnologijos - ir kokios? Kritiniai svarstymai apie Europos etnologijos prasmę ir tikslą. Lietuvos etnologija. Socialinès antropologijos ir etnologijos studijos, 2011, Nr. 11(20), p. 33-48.

[19] KUCZYŃSKA, Anna. Antropolog w Warszawie. W Warszawie i nie tylko... Migawki z anthropologii miasta. Warszawa: Mazowieckie centrum kultury i sztuki, 2011, p. 5-15.

[20] KVIESKIENĖ, Giedrė; LIEPUONIUS, Arvydas. Laisvalaikio kultūra. Iš: Lietuvos kultūros kongresas. Sud. R. Ozolas, G. Kvieskienè. Vilnius, 1991, p. 530-533.

[21] LAUČKAITÉ, Laima. Vilniaus šventės ir pramogos prieš Pirmąjị pasaulinị karą. Naujasis židinys-Aidai 2008, Nr. 11-12, p. 468-475.

[22] Lietuvių kalbos žodynas. Elektroninis variantas. 2005 [žiūrèta 201304 10]. Prieiga per internetą: <http://www.lkz.lt/startas.htm>.

[23] van MARREWIJK, Alfons. European Developments in Business Anthropology. International Journal of Business Anthropology, 2010, Vol. 1, No. 1, p. 18-36.

[24] MATULIENE, Gražina. Darbininkų laisvas nuo gamybinio darbo laikas ir jo panaudojimas.

Iš: Darbininkas. Gamyba ir laisvalaikis. Vilnius: Lietuvos mokslų akademija, Istorijos institutas, 1972, p. 136-161.

[25] MERKIENĖ, Regina. Grigiškių bandomojo popieriaus kombinato darbininkų buitis ir kultūra (2. Šeimos sudètis ir organizacija). Lietuvos TSR Mokslu Akademijos darbai, A serija,1966, t. 1, p. 157-172.

[26] MILLER, Trice Harrison. Occupational Subcultures in the Workplace. Cornell University, 1993.

[27] MOERAN \& GARSTEN. What's in a Name? Editors Introduction to the Journal of Business Anthropology. Journal of Business Anthropology, 2012, No. 1(1), p. 91-117.

[28] PANKO, Raymond R.; KINNEY, Susan T. Working Relationships: Assessing the Need for Media to Support Close Personal Relationships at Work. Proceedings of the 28th Annual Hawaii International Conference on System Sciences. IEEE Computer Society Press, 1995, p. 24-33. 
[29] POVILIŪNAS, Arūnas. Profesinès veiklos lauko tyrimo ypatumai. Sociologija. Mintis ir veiksmas, 2011, Nr. 2(29), p. 16-34.

[30] Profesija. Tarptautiniu žodžiu žodynas. Vilnius: Alma littera, 2008, p. 603.

[31] Random House Kernerman Webster's College Dictionary. K Dictionaries Ltd., 2010 [žiūrèta 2013 05]. Prieiga per internetą: <http://www.thefreedictionary.com/>.

[32] ROJEK, Chris. Leisure Theory: Principles and Practices. Basingstoke: Palgrave Macmillan, 2005.

[33] RUSSELL, Ruth V. Leisure. Oxford Encyclopedia of the Modern World. Ed. Peter N. Stearns. Oxford University Press, 2008 [žiūrèta 2013 11]. Prieiga per internetą: <http://www.oxfordreference. com/view/10.1093/acref/9780199743360.001.0001/acref-9780199743360-e-\#>.

[34] SOUKUPOVÁ, Blanka. Objectives and Program of the English Edition of the Journal of “Urban People”. Urban People Magazine, 2007, Nr. 1(20) [žiūrèta 2013 08]. Prieiga per internetą: $<$ http://lidemesta.cz/index.php?id=448>.

[35] ŠIDIŠKIENĖ, Irma. Simboliniai veiksmai lietuvių XIX a. II pusės - XX a. I pusès vestuvių apeigose. Kartografinis tyrimas. Lietuvos etnologija: socialines antropologijos ir etnologijos studijos, 2003, Nr. 3(12), p. 31-58.

[36] The American Heritage Dictionary of the English Language. Houghton Mifflin Company, 2000 [žiürèta 2013 05]. Prieiga per internetą: <http://www.thefreedictionary.com/>.

[37] What is a co-worker? [žiūrèta 2013 07]. Prieiga per internetą: <http://www.wisegeek.org/whatis-a-co-worker.htm>.

[38] VYŠNIAUSKAITĖ, Angelè. Apie šventes, papročiu ir tradicijos sampratą bei švenčių apibūdinimas. Ekspertizès: Tautinis paveldas, tradiciniai amatai, mugès, šventès, tautodailè, 2001 [žiūrèta 2012 12]. Prieiga per internetą: $<$ http://www3.lrs.lt/pls/inter/w5_show?p_r=7034\&p_d=21303\&p_k=1>.

[39] Антропология профессий. Под ред. П. В. Романова, Е. Р. Ярской-Смирновой. Саратов: Научная книга, Центр социальной политики и гендерных исследований, 2005.

[40] ЩЕПАНСКАЯ, Т. Б. Сравнительная этнография профессий: повседневные практики и культурные коды (Россия, конец XX - начало XXI в.). Санкт-Петербург: Наука, 2010.

IRMA ŠIDIŠKIENE்

\section{Localization of definitions in co-workers' leisure research}

Summary

Fellows' leisure, festivals of Vilnius co-workers and formed or imposed rituals in these communities have not been investigated in Lithuanian ethnology up to now. Therefore it is important to review the adjoining studies in order to understand and appreciate the concepts in the selected range of problems and anticipate their research approaches. The article discusses the concepts of the on-going theme on co-workers' leisure "The Citizens' Community Cultural Expression": leisure, holidays, work, profession, colleagues and citizens' culture. Co-workers' community leisure studies are one of the ways to uncover informal urban cultural expression and social ties.

Key words: leisure, festival, profession, co-workers, citizens' culture 